\title{
HISTORY OF TECHNOLOGY
}

\section{DOI: 10.32703/2415-7422-2019-9-2(15)-139-146}

\section{Berdnychenko Yuliia *}

UDC 656.078:629.33:629.425"17/20"

State University of Infrastructure and Technologies

9, Kyrylivska St., Kyiv, Ukraine, 04071

e-mail: yb08@ukr.net

https://orcid.org/0000-0001-7536-7155

\section{Petrykovets Olha}

State University of Infrastructure and Technologies

9, Kyrylivska St., Kyiv, Ukraine, 04071

e-mail: petrikovets85@gmail.com

https://orcid.org/0000-0001-5973-2570

\section{Evolution of world and domestic production of internal combustion engines}

Abstract. An in-depth and comprehensive study of internal combustion engines creation, the prominent figures' contribution to the formation and development of domestic and world science, remains a crucial task of historical studies at their present stage. The steam engine did not completely solve the energy problem, the humanity was facing. Small workshops and enterprises in the $19^{\text {th }}$ century, which made up a significant part of the industrial sector, were not always able to use it. The small steam engine had a low efficiency. Besides, using such an engine meant high costs and troubles. Small industry required an engine that would take up minimum space and could be turned on and off at any time without much preparation. The article is devoted to highlighting and dividing the development of gas, kerosene, gasoline and diesel engines into stages. The idea of such an engine was first proposed in the early $19^{\text {th }}$ century. The prerequisites for the emergence of each engine type have been considered. The important role of Philippe Lebon as the founder of gas engine design has been shown. Several inventors from different countries worked on the idea of creating engines using various types of fuel. Among them is the Belgian engineer Jean Etienne Lenoir, who suggested starting the engine with an electric spark. The engineer Augustus Otto's role in the development and construction of the first gas engine, which was more economical than a steam engine, has been shown. Thus, all the theoretical and constructive background for inventing a new type of internal combustion engine was there, the designer of which was Rudolf 
Diesel. He created and patented an internal combustion engine - "diesel", which today remains one of the most economical heat engines.

Keywords: internal combustion engine; machinery; diesel; fuel

\section{Introduction}

These days, many research scientists in the scientific and technical literature address the issues of modern internal combustion engines structure and make forecasts of the development of a power-producing unit for modern cars based on current trends in the environmental and energy field (Bey, 2018, p. 7). Considering the problems of improving the design of piston engines from a historical point of view, the stages of creating various types of internal combustion engines are of interest, as well as the technical problems that arise when they are put into production, analysis of their designs (Berdnychenko, 2018, p. 290). A lot of constructive decisions aimed at achieving the set goals did not justify themselves at certain historical stages due to the state of production technology level at that time. However, with the development of scientific and technological progress in the field of technology, the introduction of advanced achievements in the field of electronics and new materials in engine building, at the next stage of development, advanced ideas have been successfully implemented (Pisarskaya, 2018, p. 370). The purpose of the article is to study the origin and development of internal combustion engines.

\section{Research methods}

During the preparation of the article, chronological, comparative methods of historical knowledge, classification, and systematization of historical sources and bibliographic material have been used (Pylypchuk \& Strelko, 2019, p. 20).

\section{Results and discussions}

The progress in the field of internal combustion engines is closely related to the discovery and use of various types of fuel, including synthesized ones. Since the combustion rate of the mixture and the cycle parameters (compression ratio) depend on the fuel used, and to a large extent determines the power indicators of such engines. Illuminating gas became the first such fuel.

On August 26, 1801, a French engineer professor of mechanics at the School of Bridges and Highways in Paris, Philippe Lebon, filed a patent for the design of a gas engine. The driving force emerged after the explosion of the gas-air mixture inside the working cylinder - the mankind at last had an internal combustion engine. The principle of operation of this machine was based on the well-known property of the gas he discovered: its mixture with air exploded upon ignition, with the release of a large amount of heat. Combustion products expanded rapidly, exerting strong pressure on the environment. By creating the appropriate conditions, it was possible to use the released energy in the interests of man. The Lebon engine had two compressors and a mixing chamber. One compressor was supposed to pump the compressed air and the other - compressed illumination gas from the core engine into 
the chamber. The gas-air mixture then entered the working cylinder, where it ignited. The engine was double-acting, that is, alternative working chambers were located on both sides of the piston. Lebon cherished an idea of an internal combustion engine, but he was killed in 1804, before he began to realize his invention (Aleksandrov, 1999).

In subsequent years, several inventors from different countries tried to create a workable illuminated-gas engine. Among them was the Belgian engineer Jean Étienne Lenoir. Working at a galvanic plant, Lenoir came to the conclusion that the fuel-air mix in a gas engine could be ignited with an electric spark, and decided to build an engine based on this idea. In 1864, more than 300 of such engines of various powers were already produced. Having become rich, Lenoir stopped improving his machine, and this predestined its fate - it was driven from the market by a more advanced engine created by the German inventor August Otto.

In the late $70^{\mathrm{s}}$ of the $19^{\text {th }}$ century, one of the founders of the Deutz Gas Engine Factory in Cologne, engineer August Otto, managed to build the first efficient gas engine, which was more economical than the steam engines, existing at that time. However, the gas consumption in this engine, which required significant financial investments, was quite large and amounted to approximately $1.5 \mathrm{~m}^{3}$ per hour. Besides, there were very few gas plants, they were concentrated only in large cities, and economically and territorially, these circumstances impeded the widespread introduction of a gas engine into the industry, making it uncompetitive compared to a steam engine.

That is why; all efforts were aimed at finding a fuel that could replace gas. It was decided to use liquid fuel, cheap at that time, oil (The Michigan technic, 1912). However, from the start, it was not oil itself that was applied, but gasoline, as it had a small applicable scope at that time.

Initially, fuel was formed using coil-type evaporators, but as long ago as in 1885 , they were replaced by injection pumps, followed by valves, which turned into spray carburettors later. But due to the rapidly growing popularity of gasoline, it was becoming more expensive and therefore unprofitable fuel for engines. In the mid- $80^{\mathrm{s}}$ of the 19th century, the question arose of the use of cheaper liquid fuels in engines (Sass, 1962).

Originally, they tried to use oil and fuel oil, but the use of these types of fuel presented great structural difficulties, so they had to take an axe to it and switch to kerosene. So that's how a kerosene engine design appears. The first kerosene engines that complied with the market conditions can be considered the Spire engine, built in Halle (Germany), and the Priestman engine, built in Hall (England). Both engines had kerosene injection pumps. In the Spire engine, kerosene was injected into the cylinder through a red-hot tube, where it had to evaporate (Bromlej, 1900). In the Priestman engine, kerosene was injected not directly into the cylinder, but into the evaporator, which was heated by exhaust gases.

In 1888, an Englishman James Hargreaves built a self-ignition engine for heavy fuel injected by a pump onto combustion chambers. The Hargreaves' engine already 
contained all the signs of an engine with a hot bulb. At that time, Hargreaves already used a closed injector (an injection nozzle with a needle pressed by a spring, which opened under the pressure of the pump) and injected water into the cylinder to cool the combustion chamber.

Emil Kapitán from Germany, one of the talented engine designers of that time, made a ton of suggestions to solve the problems of heavy-oil engines. His most outstanding work is the proposal to inject two jets of fuel into the combustion chamber from two opposing injectors in such a way that their power in a collision is mutually destroyed and caused fine atomization of the fuel. The ignition of heavy-oil (fuel oil or coal oil) should not be with the help of hot air, but with the help of auxiliary ignition, which was the injection of a small amount of kerosene into a hot earthenware pipe (hot tube). To start the engine, it was only necessary to preheat the tube. But not one of the Kapitán heavy-oil engine projects was completed. This was explained by the lack of funds, but most likely it was because of too much passion for various new Kapitán's ideas and lack of perseverance when he failed in this field (Carpenter, 1902).

Zenlein, equal to Kapitán in genius, was the first to propose a method of airblast fuel injection in 1884. He patented a kerosene engine with air-blast kerosene injection, ignited by an electric spark. For complete combustion, Zenlein recommended to inject water.

In 1890 in Leipzig, Sviderskyi built a two-stroke engine with a single-stage compressor for fuel atomizing.

In 1887, Otto Köhler, a teacher in Cologne, published "Theory and Construction of a Rational Heat Motor". Using simple thermal calculations as an example, he outlined various cyclic processes of internal combustion engines. For instance, in this brochure, he suggests the design of an engine with compression of a ready-made working mixture, however, this compression pressing should be such as to enable the final temperature obtained due to high compression remain below the self-ignition mixture temperature. For this purpose, the intake valve should have closed earlier than usual. Köhler simultaneously studied engines with high compression pressings of clean air without fuel, which were of great interest at that time, and thus theoretically predicted the working cycle that Diesel subsequently used in his engine. Köhler points out that these engines are popular in the industry due to their theoretically high efficiency. Köhler also stated the ideal Carnot cycle in his work. He calculated an engine with such a cycle and came to the conclusion that "the ideal (Carnot) cycle, apart from difficulties in its implementation, is completely inapplicable for practical purposes" (Timan, 1931).

Thus, there were already all the theoretical and constructive prerequisites for the creation of a new type of internal combustion engine, when the Rudolph Diesel engine appeared (Dizel', 1892). In 1892, Diesel patented an internal combustion engine cycle (Dizel', 1893), herewith he was granted a patent as follows:

1. The internal combustion engine cycle is characterized by the fact that the piston in the cylinder compresses the air or some other gas (steam) so hard that the 
resulting compression temperature is much higher than the flash point of fuel. Herewith, the combustion of fuel gradually introduced after the dead centre is so that no significant pressure and temperature occur in the engine cylinder. Following this, after a fuel stop, further expansion of the gas mixture takes place in the cylinder.

2. To carry out the cycle described in paragraph 1, a multi-stage compressor with a receiver shall be connected to the working cylinder. It is possible to connect several working cylinders with each other or with cylinders for preliminary compression and subsequent expansion.

Thus, only isothermal combustion was patented. As can be seen from the Diesel patent, such combustion was meant to keep the combustion temperature low (not more than $700-900^{\circ} \mathrm{C}$ ) in order to avoid water cooling of the cylinders. The heat removed with water after cooling can be used for repeated work (Diesel, 1893). This engine was meant to serve as a rational heat engine and was intended to replace the steam engine and existing heat engines (Gumilevskij, Dizel', 1938).

Rudolph Diesel tirelessly worked on his engine, using his predecessors' and critics' theoretical justifications (Diesel, 1912). Between 1893-1897, accumulating theoretical and practical experience through this process, with the companies of F. Krupp and MAN money, Diesel and his colleagues created an engine, which in its finished design had nothing to do with the "rational", originally patented heat isothermal combustion engine (Bergen, 1991). The foresight of his ideas should be noted, some of which have been implemented these days, and some have yet to be realized. This is the possibility of engine operation on various fuels, including solid, liquid and gaseous, as well as their mixtures. He attributed coal dust and vegetable oils to them. This is also a multi-stage fuel feed, which can be carried out by modern electronically controlled systems. In 1908, Rudolf Diesel's patents expired, and factories all around the world began to manufacture his engine thus testifying the fact of his developments recognition.

\section{Conclusions}

These days, the name Diesel has become outstanding. Even if one considers that Diesel patented in its patent applications the processes far from those embodied in the engine, he nevertheless created and constructed the internal combustion engine - the "diesel engine", which until now is one of the most economical heat engines.

It can be concluded that internal combustion engines are nowadays widespread in various sectors of the national economy. They are especially widely used in land, water and air transport.

\section{References}

Aleksandrov, N. I. (1999). Dizel': chelovek i motor [Diesel: man and engine]. Dvigatel' - Engine, 4, 27-31 [in Russian].

Berdnychenko, Y. A., \& Kyrychenko, H. I. (2018). Doradchi z'izdy inzheneriv sluzhby rukhomoho skladu i tiahy: diialnist L. M. Levi [Consultative congresses of the rolling stock and traction engineers: activity of L. M. Levi]. Istoriia nauky 
$i$ tekhniky - History of Science and Technology, 8(2(13), 284-296. https://doi.org/10.32703/2415-7422-2018-8-2(13)-284-296 [in Ukrainian].

Bergen, L. A. (1991). Podvig i tragediya Rudol'fa Dizelya [The feat and tragedy of Rudolf Diesel]. Morskoj flot - Navy, 5, 33-35 [in Russian].

Bey, N. O. (2018). Evoliutsiia svitovoho ta vitchyznianoho vyrobnytstva avtomobilnykh dvyhuniv (XVIII - pochatok XXI stolit) [Evolution of world and home production of motor-car engines (XVIII - the beginning of the XXIst centuries)]. Istoriia nauky i tekhniky - History of Science and Technology, 7(11), 6-17. https://doi.org/10.32703/2415-7422-2017-7-11-6-17 [in Ukrainian].

Bromlej, E. E. (1900). Gazovye, benzinovye i kerosinovye dvigateli [Gas, gasoline and kerosene engines]. Moskva: Tipografiya I. A. Balandina [in Russian].

Carpenter, R. C. (1908). Internal combustion engines, their theory, construction and operation. London: Van Nostrand Company.

Diesel, R. (1893). Theorie und Konstruktion eines rationallen Wärmemotors zum Ersatz der Dampfmaschinen und der neute bekanten Wärmemotoren. Berlin.

Diesel, R. (1912). The Diesel Oilengine. The Diesel Oil-Engine, and its Industrial Importance Particularly for Great Britain. Engineering, 35-36, 395-406.

Dizel', R. (1892). Rabochij process $i$ sposob vypolneniya odnocilindrovogo $i$ mnogocilindrovogo dvigatelya [Workflow and method of performing a singlecylinder and multi-cylinder engine]. Patent Germanii № 67207 [in Russian].

Dizel', R. (1893). Izmenenie formy krivoj $u$ dvigatelej vnutrennego sgoraniya $i$ podacha goryuchego szhatym vozduhom posredstvom kompressora [Changing the shape of the curve in internal combustion engines and supplying fuel with compressed air through a compressor]. Patent Germanii № 82168 [in Russian].

Friedrich, S. (1962). Geschichte Des Deutschen Verbrennungsmotorenbaues: Von 1860-1918. Göttingen, Heidelberg: J. Springer, 667 p.

Gumilevskij, L. (1938). Rudol'f Dizel' [Rudolph Diesel]. Moskva, Leningrad: GONTCH [in Russian].

Pisarskaya, N. V. (2018). Vyhotovlennia husenychnykh mashyn na Kharkivskomu traktornomu zavodi (seredyna XX - pochatok XXI st. [Manufacturing tracked vehicles at the Kharkov Tractor Plant (mid-twentieth - beginning of the twentyfirst century)]. Istoriia nauky $i$ tekhniky - History of Science and Technology, 8(2(13), 368-375. https://doi.org/10.32703/2415-7422-2018-82(13)-368-375 [in Ukrainian].

Pylypchuk, O., \& Strelko, O. (2019). Work in the interests of rail transport: the second Minister of Railway Transport of the Russian Empire - Volodymyr O. Bobrynskyi (1869-1871). Istoriia nauky i tekhniky - History of Science and Technology, 9(1(14), 19-32. https://doi.org/10.32703/2415-7422-2019-9-1(14)19-32 [in Ukrainian].

The Michigan technic (1912). Engineering Society. University of Michigan, College of Architecture and Design, 27, 206.

Timan, A. E. (1931). Bystrohodnye transportnye dizelya [High-speed transport diesel]. Moskva: OGIZ Gostransizdat [in Russian]. 


\section{Бердниченко Юлія}

Державний університет інфраструктури та технологій 9, вул. Кирилівська, Київ, Україна, 04071

\section{Петриковець Ольга}

Державний університет інфраструктури та технологій 9, вул. Кирилівська, Київ, Україна, 04071

\section{Еволюція світового та вітчизняного виробництва двигунів внутрішнього згорання}

Анотація. Розгорнуте та всебічне дослідження створення двигунів внутрішнього згорання, внеску видатних діячів у становлення та розвиток вітчизняної та світової науки, залишається актуальним завданням історичної науки на сучасному етапі ї̈ розвитку. Паровий двигун не до кіния вирішував енергетичну проблему, що стояла перед людством. Невеликі майстерні $i$ підприємства в XIX столітті, які складали значну частину промислового сектора, не завжди могли ним скористатися. Маленький паровий двигун мав невисокий коефіиієет корисної діï. Крім того, використання такого двигуна було пов'язано з великими витратами і клопотами. Для дрібної промисловості був потрібний двигун, який був би не громіздкий, який можна було б включати $i$ зупиняти в будь-який час без довгої підготовки. Стаття присвячена висвітленню та періодизачії етапів розвитку газових, керосинових, бензинових та дизельних двигунів. Вперше ідея такого двигуна була запропонована на самому початку XIX століття. Розглянуто передумови виникнення кожного типу двигунів. Показано важсливу роль Філіпа Лебона, як фундатора ідеї конструкиї газового двигуна. Декілька винахідників з різних країн працювали над ідеєю створення двигунів на різних видах палива. Серед них $і$ бельгійський інженер Жан Етьєн Ленуар, який запропонував запускати двигун за допомогою електричної іскри. Висвітлена роль інженера Августа Отто в розробиі $i$ побудові першого газового двигуна, який був більш економічний ніж паровий. Таким чином виникли всі теоретичні та конструктивні передумови для нового типу двигуна внутрішнього згоряння, конструктором якого став Рудольф Дизель. Він створив $і$ запатентував двигун внутрішнього згорання - «дизель», який і сьогодні залишається одним з найбільш економічних теплових двигунів.

Ключові слова: двигун внутрішнього згорання; техніка; дизель; паливо

\section{Бердниченко Юлия}

Государственный университет инфраструктуры и технологий 9, ул. Кириловская, Киев, Украина, 04071 


\title{
Петриковец Ольга
}

Государственный университет инфраструктуры и технологий

9, ул. Кириловская, Киев, Украина, 04071

\section{Эволюция мирового и отечественного производства двигателей внутреннего сгорания}

\begin{abstract}
Аннотация. Развернутое и всестороннее исследование создания двигателей внутреннего сгорания, вклада выдающихся деятелей в становление и развитие отечественной и мировой науки, остается актуальной задачей исторической науки на современном этапе ее развития. Паровой двигатель не до конща решал энергетическую проблему, стоявшую перед человечеством. Небольшие мастерские и предприятия в XIX веке, которые составляли значительную часть промышленного сектора, не всегда могли им воспользоваться. Маленький паровой двигатель имел невысокий коэффициент полезного действия. Кроме того, использование такого двигателя было связано с большими затратами и хлопотами. Для мелкой промышленности требовался двигатель, который был бы не громоздкий, который можно было бы включать и останавливать в любое время без долгой подготовки. Статья посвящена освещению и периодизации этапов развития газовых, керосиновых, бензиновых и дизельных двигателей. Впервые идея такого двигателя была предложена в самом начале XIX века. Рассмотрены предпосылки возникновения каждого типа двигателей. Показана важная роль Филиппа Лебон, как основателя идеи конструкиии газового двигателя. Несколько изобретателей из разных стран работали над идеей создания двигателей на различных видах топлива. Среди них и бельгийский инженер Жан Ленуар, который предложил запускать двигатель с помощью электрической искры. Освещена роль инженера Августа Отто в разработке и построении первого газового двигателя, который был более экономичный, чем паровой. Таким образом, возникли все теоретические и конструктивные предпосылки для нового типа двигателя внутреннего сгорания, конструктором которого стал Рудольф Дизель. Он создал и запатентовал двигатель внутреннего сгорания «дизель», который и сегодня остается одним из наиболее экономичных тепловых двигателей.
\end{abstract}

Ключевые слова: двигатель внутреннего сгорания; техника; дизель; топливо

Received 20.06.2019

Received in revised form 25.08.2019

Accepted 27.09.2019 